Ass. Univ. Bull. Environ. Res. Vol. 13 No. 2, October 2010

UCES

\title{
COMPARATIVE STUDY IN MIDGUT HISTOLGICAL STRUCTURE OF QUEEN AND WORKER YEMENI HONEY BEES APIS MELLIFERA JEMENATICA (HYMENOPTERA: APIDAE) IN PUPAE AND ADULT STAGES UNDER NATURAL NUTRITION
}

\author{
Aljedani, D. M.*, Al-Ghamdi, A. A.** and Almehmadi' R. M. \\ *\&*** Department of Zoology, Girls College, King Abdul-Aziz University \\ Saudi Arabia, 19516, Jeddah 21445 \\ E-mail: d_almehmadi@yahoo.com \\ ralmehmadi@kau.edu.sa \\ **King Saud University, E-mail: aalkhazim@hotmail.com
}

\begin{abstract}
:
The histological structures of the midgut (ventriculus) at the pupal and adult stages of queen and worker honey bees from the Yemeni honey were studied. The results of this study illustrate the amazing and complex structure of this insect. It is noteworthy that this research proves that queen honey bees differ from worker honey bees in terms of the developmental stages that they undergo at various times. Further, the midgut undergoes singular levels of development throughout various stages of metamorphosis. The pupal stage of the queen has been thoroughly studied, but that of the worker has only been studied on the first, fourth, and seventh days. However, the adult stage of the newlyemerged queen honey bees, newly-emerged worker honey bees, nurse worker honey bees, and forager worker honey bees all been studied. The results indicate that the tissues of the midgut, or ventriculus, during the pupal stage were reformed. The ventriculus revealed early development of the flections. It also revealed the presence of a group of prolonged epithelial cells and the absence of the peritrophic membrane. In addition, the cavity was almost empty of any components of food. However, during the adult stage, the tissues were distinguished in order to fit the bee's functions, and to accommodate the type of food. The midgut was composed of several regular flections which are comprised of the columnar cells, and muscles were characterized by the clear presence of a large number of regenerative cells. Therefore, the study found that the tissues of the queen honey bee, throughout various stages, were more advanced than that of the worker honey bee. Moreover, it was found that the kind of food that bee consumes has a clear impact on the structure of the midgut.
\end{abstract}

\section{INTRODUCTION:}

The digestive canal of honey bees (Apis mellifera $\mathbf{L}$.) consists of the foregut, which is composed of the Stomodeal valve, the undifferentiated midgut; and the hindgut, which is composed of the Ileum and the rectum (Snodgrass (1984). The available research indicates that the histological studies of the 
pupal stage (i.e., following up the changes that occur in the digestive canals of the queen and worker honey bees were few, on the grounds that this stage is considered to be an intermediary within the transformation process and is not furnished with nourishment. In theory, in a study by Katarzyna and Zofia (1988) which examine the pupal stage, it was found that most fatty tissues undergo a process of destruction during the course of histological alteration. The elder pupa's fatty tissues, especially those found at the top of the abdomen pass through a regenerating process which included cellular destruction in order to be organized. During the prepupal stage, the midgut becomes narrower and longer. However, the midgut of the white-eyed queen pupa takes on the form of a bottle or jug and become wider. In comparison, the midgut of the pink-eyed queen pupa become parallel, and the top or the edges of the cell externally drop in the gut's cavity. Yet, the epithelial cells of the black-eyed queen pupa are similar to those found at the adult stage. (Snodgrass 1984; Cruz-Landim and Mello 1970; Neves et al. 2002). The epithelial cells' wall within the newly-emerged queen pupa has been already re-structured, and the digesting cells and the generative cells are already characterized. As for the advanced queen pupa, the epithelial cells of the midgut have become complete and are similar to the structure of the midgut of the insect as a whole. (Billingsley 1990; Sadrud-Din et al. 1996; Diaz et al. 1998, 2000, 2003; Garcia et al. 2001; SilvaOlivares et al. 2003; Rost et al. 2005). At the
Hymenoptera level, the midgut's changes begin at the prepupal stage with the epithelia of the larval stage, leaving only the basement membrane and the regenerative cells. At the same time, some cells are to be multiplied and accumulated on the basement membrane in order to form new epithelial cells for the queen pupa. (Snodgrass 1984; Cruz-Landim and Mello 1970; Gama and Cruz-Landim 1984; Neves et al. 2002; Martins et al. 2006).In the adult stage, the midgut's epithelia is divided into three regions: the top, which contains long organelles and endocrine granules; lysosomes, oralternate bodies; and microfilaments. The middle part contains the nucleus, endoplasmic network, and Golgi bodies. The basement part consists of membranous flections that are associated with mitochondria (Cruz-Landim 1985). The midgut epithelia of the honey bee consists of three types of cells which include the columnar, or so-called digestive cells; the regenerative cells; and the glandular endocrine cells. The epithelial cells are responsible for the secretion of the digestive enzymes and the absorption of the digested food. Serrão and Cruz-Landim (1995a), Snodgrass (1984), and Martins et al. (2006) found three types of cells in the midgut of the worker honey bees. The first type of cells consists of the digestive cells that manufacture the digestive enzymes to absorb the digested food; the second type includes the endocrine cells that produce the hormones; and the third type consists of the regenerative cells, which are responsible for the process of alternation and compensation for the two aforementioned 
types of cells. Thus, it was identified the regenerative cells, which have the least amount of cytoplasm, contain nuclei of concentrated chromatin. The cytoplasm contains a small amount of ribosomes, mitochondria, Golgi bodies, and an endoplasmic network. This composition implies that those cells have low metabolic activity. (Cruz-Landim 1985; CruzLandim et al. 1996; Cruz-Landim 1999; Martins et al. 2006). The digestive canal of the adult stage consists of the foregut, which beginsin the pharynx; the oesophagus; the crop; the proventriculus; and the midgut; or (ventriculus. Thus, the hind gut is divided into the pylorus, the ileum, and the rectum (Snodgrass 1984; Cruz-Landim 1985; Serrão and Cruz-Landim 1995b; Cruz-Landim 1999; Martins et al., 2006). The present envistigation aimed to compare the midgut histological structure for pupa and adult stages of both of queen and worker Yemeni honey bees at different developmental stages under natural nutrition.

\section{MATERIALS AND METHODS:}

The Yemeni honey bee, Apis mellefera jemenatica used in the present investigation were originated at the apiary of research statios of Hada Al-Sham Faculty of Meteorology, Environment in King Abdul-Aziz University during active seasons of 2007 and 2008. Among the key morphological characteristics that distinguish its species the Yemeni honey bee is considered to be the smallest type of yellow bee.

Healthy honeybee colonies of a bout equal strength were used for the queen-rearing program. The Doolittle, method was used to obtain the different stages and ages. The queenrearing operation was carried out under normal conditions.

\section{1-Used individuals:}

A-Pupal stage: The chosen bees consist of queen pupa were 1, 2 and 3-days old, and worker pupae were 1, 4 and 7 days old.

B-Virgin queen: was newly-emerged performed .

C-Beeworkers: Three different ages as follows:

C-1-Newly-emerged workers (From 0 to 12 hours-old).

C-2- Nurse bees: (was 3 to 6 days old).

C-3- Bee forages.

\section{2-Age determination:}

One comb was selected to type the date of the day on, or the spaces on more than one comb. They contain the day-old eggs, which are perpendicularly placed inside the brood. After three days, the eggs hatch. The larvae continue to grow through the fifth day. At that point, the larva transforms into a pupa bee after the larval fifth metamorphosis concludes, following 13 days of egg-laying or 6 days after closing the brood.

The age of the worker honey bees have been identified as those which were newly-emerged and observed either during their emergence or directly after it. They can be determined by putting the embryo into an incubator at a $33 \mathrm{~m}$ 
temperature with $65 \%$ relative humidity in order to cultivate a 24 -hour old worker bee. The newly-emerged worker honey bees were marked with colors to count their different ages.

\section{3-Queen breeding:}

The study employed the so-called doolittle, or grafting, method, in which grafting occurs in wax cups in order to raise queens of different stages and ages. Samples of the histological study were applied to individuals that have not been subjected to any unnatural treatment. Thus, by maintaining the individuals for natural feeding, their health and disease-free status were confirmed. Approximately 10 individuals of each age were separated and placed into a conservation solution.

\section{Histological tructure:}

The samples that were to be used for the histological study were taken via the previously employed method of anatomic. Then, the steps of installing, washing, removing water, leaching, pitting, trimming, and cutting were carried out, along with marking of the parts with haematoxylin and eosin, in accordance to the general methods described in Al-Hajj's 1998 study. Then, they were examined and graphed with the assistance of an Olympus-Bx41 microscope.

\section{RESULTS:}

\section{Midgut of pupal Stage:}

\section{1-Bee queens:}

\section{A-The Queen pupa1-day-old:}

The ventriculus (vent) was characterized by a prolonged pipe configuration that spanned most of the body cavity. Fractions were beginning to appear, and a group of mediumlength epithelial cells (epth), similar to the columnar epithelial cells of nuclei (nu) formed a false epithelial layer at various levels. At the top of the cells, several vacuoles (vac) appeared. They were internally lined with a thin layer of striated border (SB) that barely recognizable due to the absence of the peritrophic membrane (PM). The cavity of the ventriculus, which was nearly void of any nutrients, was surrounded by a layer of undifferentiated muscles (M), as observed at the larval stage (Fig. 1-A, 1-B, and 1-C).

\section{B-Queen pupae 2-days-old:}

Internal development was similar to that observed in the day-old queen pupa, but the flections found in it were clear and the distinct epithelial cells (epth) of nuclei (nu) were also found at one level. At the tops of the cells, several vacuoles (vac) appeared, along with regenerative cells (RG) at the basement of the cells. They were surrounded by a layer of longitudinal muscles (LMSCL), followed by the circular muscles (CMSCL), (Fig. 1-D and 1-E).

\section{C-Queen pupae3-days-old:}

Internal development closely resembled that of the two-day-old pupa, but its flections were clear, longer, and internally extended, and consisted of a group of long epithelial cells (epth) of clear nuclei (nu). Several vacuoles (vac) were observed at the tops of the cells. The 
vacuoles were internally lined with a thin layer of striated border (SB) and marked by the presence of a group of small digestive epithelial cells that secreted a large amount of enzymes. Further, regenerative cells (RG) were found in large numbers at the basement of the cells. They were surrounded by a layer of longitudinal muscles (LMSCL), followed by the circular muscles (CMSCL), which faced the outside (Figs. 1-F, 1-G, and 1-H).

\section{2-Bee workers:}

A-Worker pupae 1-day-old:

The internal structures were similar to those found in the day-old queen pupa, but the flections were not yet differentiated. The epithelial cells were found at different levels, where they formed a false epithelial layer. The undifferentiated muscles were found to be in a similar state of development as that associated with the larval stage (Figs. 2-A and 2-B).

\section{B-Worker pupae 4-days -old:}

The Pupae of the Worker Honey Bee, $4^{\text {th }}$ Day:

Internal development was characterized by the presence of flections. The cavity of the ventriculus was determined to be void and the epithelial cells (epth) were placed away, including spaces, at their bottoms of undifferentiated nuclei (nu). At the top of the cells, several vacuoles (vac) were observed with the presence of a set of small digestive epithelial cells, especially at the tops of the cells. Further, large numbers of regenerative cells (RG) appeared in close groups at the basement of the cells, surrounded by a layer of longitudinal muscles (LMSCL) and circular muscles (CMSCL) that faced the outside (Figs. 2-C \& 2D).

\section{C-Worker pupae 7-days- old:}

Internal structures resembled those found in the four-day-old queen pupa, but the flections were found to be clear. The peritrophic membrane (PM) was beginning to appear, and an increased number of vacuoles (vac) and small digestive epithelial cells were observed as well (Fig. 2-E and 2-F).

\section{The Histological Results of the Midgut} (Ventriculus) at the Fourth Stage:

The ventriculus was followed by the proventriculus. It bows inside the cavity of the body and its lining is characterized by many flections. The epithelium of the ventriculus begins at the basement of the external plate of central valve which refers to the end of the ectodermic part of the canal and the beginning of the ventriculus of endodermic origin. In the present study, it was found that:

\section{1-Queen Pupae:}

The midgut (ventriculus) of the queen consists of many regular fractions that, in turn, consist of two types of epithelial cells. The first type consists of columnar cells. The presence of layers of epithelial cells (epth) of clear nuclei (nu) at different levels was noticed, as well as the presence of a layer of striated border (SB) on the inside. The presence of a layer of small 
epithelial digestive cells that resemble small proliferate were observed. These cells arose from the epithelial of the ventriculus and resulted from the division of large numbers of epithelial cells that lined the epithelium of the ventriculus with a peritrophic membrane (PM). The second type of the epithelial cells were clearly noted and appeared as large numbers of the regenerative cells (RG) as surrounded by a good layer of longitudinal muscles (LMSCL) on the inside and the circular muscles (CMSCL) on the outside (Figs. 3-A and 3-B).

\section{2-Bee Workers:}

The histological structure of the newlyemerged worker honey bees' midguts (ventriculus) differed from that of the nurse worker honey bees or the forager worker honey bees.

\section{A-New-Emerged Workers:}

The flections were found in smaller amounts than that found in the queen honey bee. The columnar cells were spaced from each other fairly well, and there was a layer of small digestive epithelial cells that resembled a small proliferate that arose from the epithelium of the ventriculus and resulted from the division of large numbers of epithelial cells which lined the epithelial of the ventriculus by a peritrophic membrane (PM). The clarity of large numbers of the regenerative cells (RG) were surrounded by a layer of longitudinal muscles (LMSCL) on the inside and circular muscles (CMSCL) on the outside (Figs., 3-C and 3-D).

\section{B-Nurse Bees:}

An increase in the interior flections was observed. The epithelial cells (epth) were stacked next to each other, and there was an increase in the small digestive epithelial cells that cover the epithelium of the ventriculus. They result from the division of the epithelial cells. An increase in the number of the regenerative cells (RG) were found in large numbers at the basements of the cells (Figs., 3-E and 3-F).

\section{C-Bee foragers:}

The epithelial cells (epth) are found to be compact. The spaces between them became small. A decrease in the amount of small digestive epithelial cells (PF) was noticed, as well as the presence of layers of cells at different levels, and the regenerative cells (RG) were clearly seen in small numbers (Figs., 3-G \&3-H). 

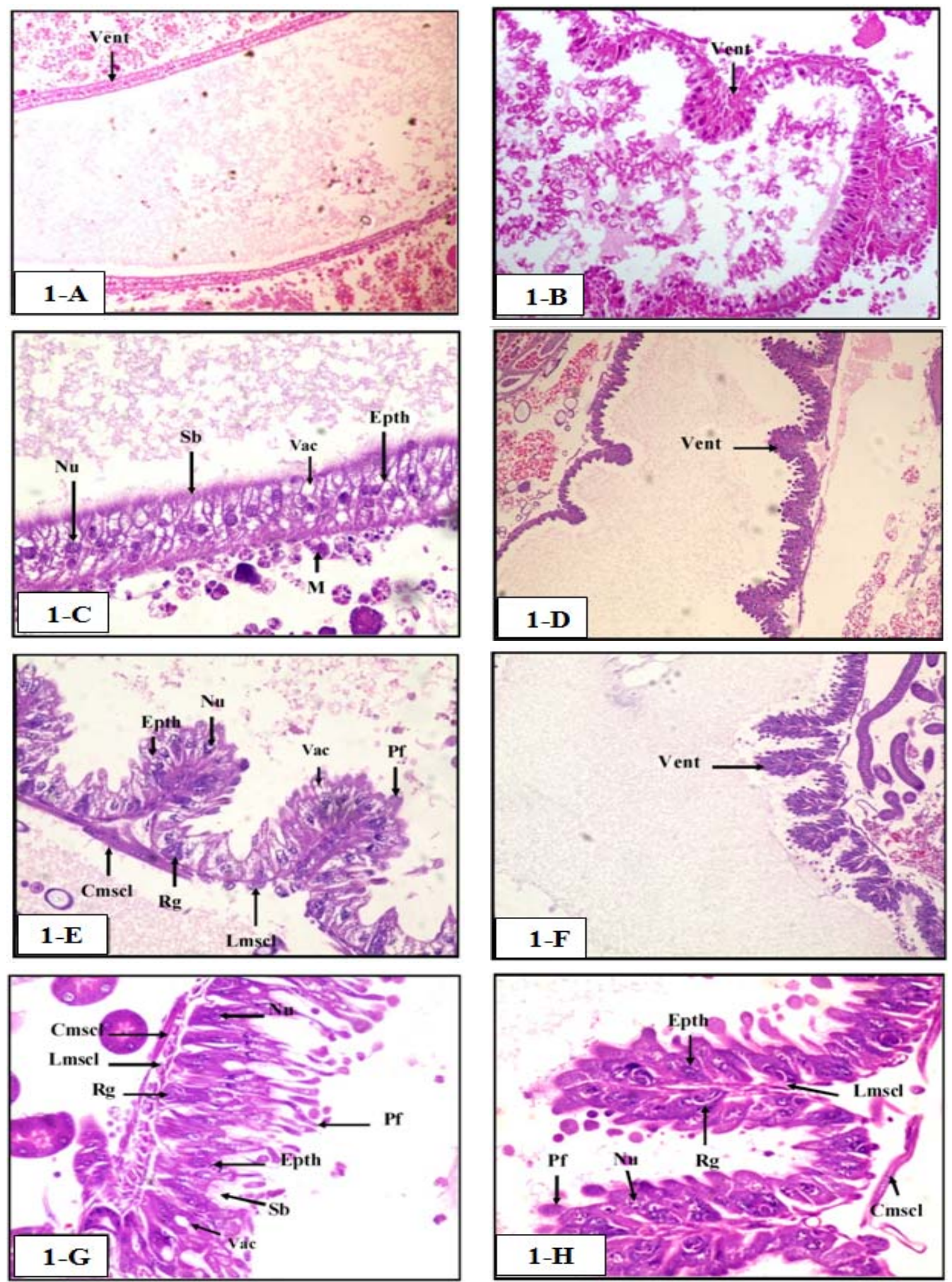

Fig.(1): $A+B(x-100), C(x-400)$ Longitudinal section of the midgut (ventriculus) in the pupa $1^{\text {st }}$ day old honey bee queen ..D(x-100) $E(x-400)$ in the pupa $2^{\text {nd }}$ days old honey bee queen. $F(x-100) G+H(x-400)$ in the pupa $3^{\text {rd }}$ days old honey bee queen. Cmscl: circular muscles. Epth: epithelium cells. Lmscl: longitudinal muscles. M: muscles. Nu : nucleus . Pf: proliferating small epithelium digestive cells. Rg: regenerative cells. Sb: striated border. Vac: vacuoles.Vent: ventriculus 

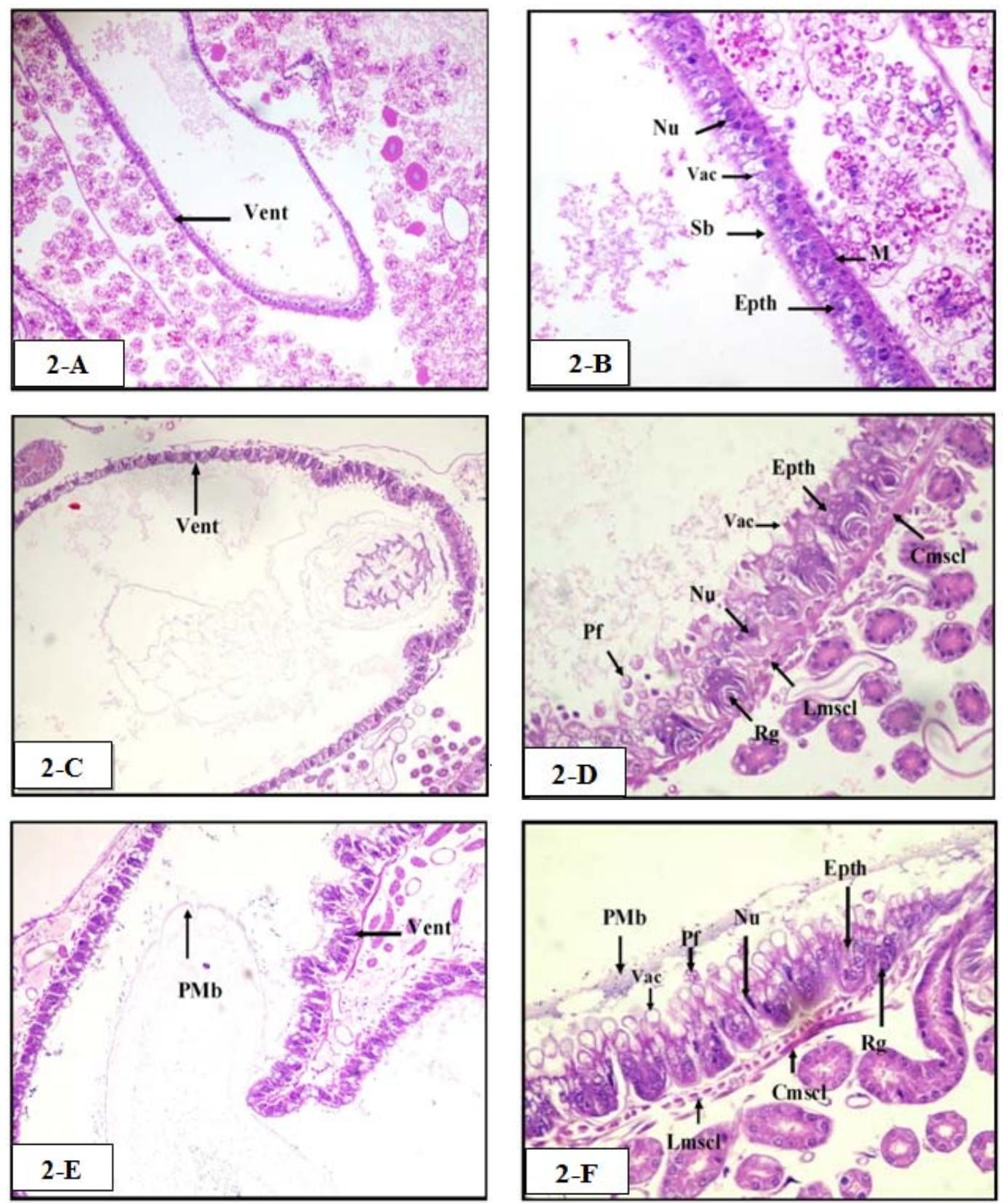

Fig. (2): Longitudinal section of the midgut (ventriculus), $A(x-100), B(x-400)$ in the pupa $1^{\text {st }}$ day old honey bee worker. $C(x-100) D(x-400)$ in the pupa $4^{\text {th }}$ days old honey bee worker. $E(x-100) F(x-400)$ in the pupa $7^{\text {th }}$ days old honey bee worker. Cmscl: circular muscles. Epth: epithelium cells. Lmscl: longitudinal muscles. M: muscles. $\mathrm{Nu}$ : nucleus . pMb: peritrophic membrane. Pf: proliferating small epithelium digestive cells. Rg: regenerative cells. Sb: striated border. Vac: vacuoles. Vent: ventriculus 

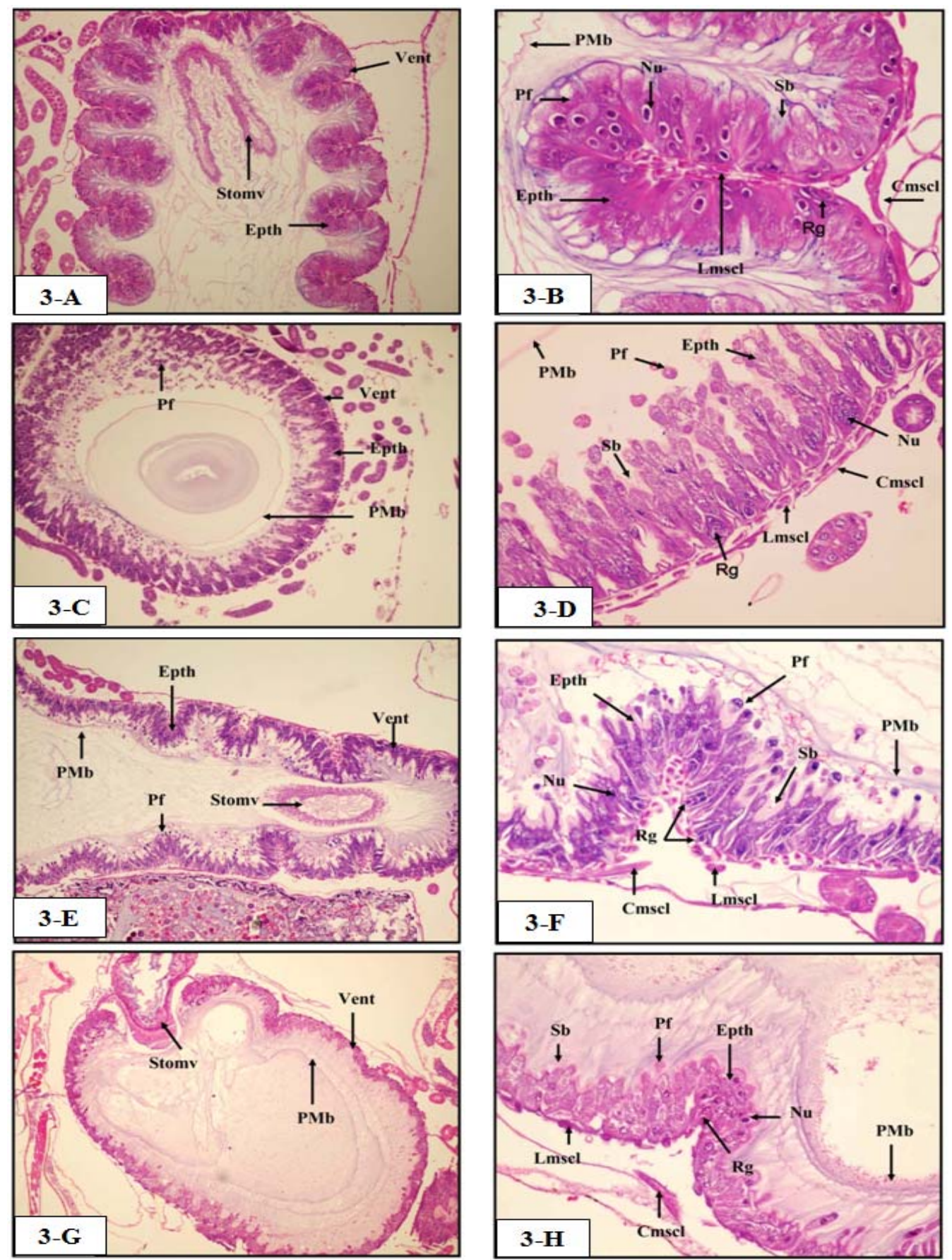

Fig. (3): A ( $x-100) B(x-400)$ Longitudinal section of the midgut (ventriculus) in the honey bee virgin queen. $C(x-100), D(x-400)$ in the newly emerged honey bee workers. $E(x-100), F(x-400)$ in the nurse honey bee workers. $G(x-100), H(x-400)$ in the foragers honey bee workers. Cmscl: circular muscles. Epth: epithelium cells. Lmscl: longitudinal muscles. M: muscles. Nu : nucleus . PMb: peritrophic membrane. Pf: proliferating small epithelium digestive cells. Rg: regenerative cells. Stomv: stomodaeum valve. Sb: striated border. Vac: vacuoles.Vent: ventriculus 


\section{DISCUSSION:}

This study examined the histological structure of the midgut of queen and worker honey bees of the Yemeni honey bee species Apis mellifera jemenatica. The results of the study illustrated the perfect and awesome structure of this insect. Differences between the queens and the workers have been highlighted in terms of their different stages and the different ages that are associated with each stage.

\section{Midgut of Pupal Stages:}

This study found that the queen pupas have fewer regenerative cells than the worker pupas. In addition, the peritrophic membrane was not found in the three-day-old queen pupas, whereas it was present in the seven-day-old worker pupas. This development is attributed to the kind of food which was consumed and the bee's future physiological functions at the time when it moved from the pupal to the adult stage. The flections appeared in the ventriculus of the worker honey bee, likely because of the increased absorption space. The transformation process begins at the pre-pupal stage, after the closure of the brood, which includes removal of the larva's epithelium from the ventricular cavity. Then, a new epithelial cell was formed by the division of the essentially regenerated cells. It was unclear whether the epithelial cells in the midgut of the larvae have been fully tended, or if some of them were left for the adult stage. In fact, the major damage could be seen at the top of the cells that contained vacuoles and bulbous protrusions that were related to the cell and its head, which was placed towards the cavity of the ventriculus. Such is consistent with CruzLandim's and Cavalcante's (2003) findings.

\section{Midgut of Adult Stage:}

The ventriculus follows the proventriculus. It bends within the body cavity to form a $\mathrm{U}$ shape. It is here that the process of digestion and food absorption takes place. The lining of the ventriculus contains several flections that allow a large amount of food to pass for easy digestion and absorption, whereupon the cells of the ventriculus secrete the enzymes that help the digestion of food process (Al-Hefny 2005). The epithelium of the ventriculus begins at the basement of the external plate of the central valve, which refers to the end of the ectodermic portion of the canal and the beginning of the ventriculus of endodermic origin. The epithelium of the ventriculus is surrounded by a peritrophic membrane (PM), which is considered a barrier that protects the epithelium cells from the contents of food (e.g., pollen). A cellular wall is surrounded by a layer of muscle fibers. According to Raes et al. (1994), the regenerative cells resemble nests in the epithelium of the adult honey bee's midgut. Further, Cruz-Landim et al. (1996) described the regenerative cells of the honey bee as a combination that consists of a group of nests located on the same level of the basement of the digestive cells. They also found that the edges of the regenerative cells do not extend to the cavity. Such an observation is consistent with the findings of Cruz-Landim (1985), Serrão and 
Cruz-Landim (1995 b), and Cruz-Landim and Cavalcante (2003). Generally speaking, the endocrine cells within insects' midguts cannot be viewed by an optical microscope (Neves et al. 2003). In physiological terms, it was found that the columnar cells are digestive cells, whereas the regenerative cells' physiological function is to regenerate the damaged cells (Cruz-Landim et al. 1996). The regenerative cells were found during the process of differentiation in both the larval and adult stages, an observation which is consistent with findings from Raes et al. (1994) and Cruz-Landim et al. (1996). The role of the regenerative cells, as noted at the larval stage, does not depend on the increase in the size and number of the digestive cells, but there is a mechanism for it that might be responsible for the increase in the surface of the epithelium of the midgut of the bees. In addition, the increase in the size and number of regenerative cell nests may play a role in filling the spaces between the digestive cells through the growth of the midgut (Martins et al. 2006). The increased number of secreted cells, which consist of decomposed digestive cells, is accompanied by an increase in the number of the regenerative cells to compensate for the alternation of the epithelial cells by other new cells. A study conducted by Jimenez and Gilliam (1990) indicates that the structure of the honey bee's midgut is more complex than a simple tube of similar epithelial cells. It seems that there are a number of physiological details associated with the midgut of the honey bee that merit further study. The results of the histological study supported the results of the anatomical study of the entire age span of worker honey bees, in terms of the external appearance of the ventriculus as well as its size and shape. There were simple flections in the ventriculus of the newly-emerged bee which were manifested in the histological part, and the increase in the size of the ventriculus and its deep flections in the anatomical study appeared evident in the histological study of the nurse honey bees. In addition, the presence of the ventriculus as a coherent bloc of rare flections resembles a homogeneous bloc in the forager honey bees, a fact that was supported by the histological study.

\section{REFERENCES:}

Al-Haaj, H. A. (1998): Preparations microoptical (microscopic technology) the theoretical foundations and applications, the first edition: The Books of Jordan, Amman - Jordan (331 pages).

Al-Hefny, A. M., (2005): Beekeeping, Jeddah: Scientific Publishing Center - King Abdul Aziz University (591 pages).

Billingsley, P.F. (1990): The midgut ultrastructure of hematophagous insects. Annual Review of Entomology, 35:219-248.

Cruz-Landim, C. (1985): Ultra-estrutura e função do tubo digestivo dos insetos, Aciesp., 44: 28-49. (C.F. (Martins et al., 2006))

Cruz-Landim, C. (1999): Ultrastructral features of the regenerative cells of the bees (Hymenoptera. Apidae) midgets, Sociobiology, 34: 597-603. 
Cruz-Landim, C. and Cavalcante, V. M. (2003): Ultrastructural and cytochemical aspects of metamorphosis in the midgut of Aips mellifera L. (Hymenoptera: Apidae: Apinae), Zoological Sciences, 20: 10991107.

Cruz-Landim, C. and Mello, M. L. S. (1970): Post-embryonic changes in Melipona quadrifasciata anthidioides Lep. IV. Development of the didestive tract. Boletim de, Zoologia e Biologia Marinha., 27: 229-263.

Cruz-Landim, C., Silva-de-Moraes, R. L. M. and Serrão, J. E. (1996): Ultrastructural aspects of epithelial renewal in the midgut of adult worker bees (Hymenoptera. Apidae), Journal of Comparative Biology, 1: 29-40.

Diaz, E; Cisneros, R; Zuniga, G. and UriaGalicia, E. (1998): Comparative anatomical and histological study of the alimentary canal of Dendroctonus parallelocolis, D. rhizophagus, and $D$. valens (Coleoptera: Scolytidae), Annals of Entomological Society of America., 91: 479-487.

Diaz, E.; Cisneros, R. and Zuniga, G. (2000): Comparative anatomical and histological study of the alimentary canal of the Dendroctonus frontalis (Coleoptera: Scolytidae) complex, Annals of Entomological Society of America, 93: 303-311.

Diaz, E; Arciniega, O; Sanchez, L; Cisneros, R and Zuniga, G. (2003): Anatomical and histological comparison of the alimentary canal of Dendoctonus sp., D. ponderosae, D. pseudotsugae, $D$. rufipennis and $D$. terebrans (Coleoptera:Scolytidae), Annals of Entomological Society of America, 96: 144-152.

Gama, V. and Cruz-Landim, C. (1984): Morfologia do tubo digestivo de Camponotus (Myrmothrix) rufipes (Fabricius, 177) (Hymenoptera, Formicidae) durante a metamorphose, Naturalia, 9: 43-55. (C. F. (Martins et al., 2006)).

Garcia, J. J.; Li., G., Wang, P., Zhong, J. and Granados, R. R. (2001): Primary and continous midgut cell cultures from Pseudaletia unipunctata (Lepidoptera, Noctuidae), in Vitro Cellular and Developmental Biology-Animal, 37: 353359.

Jimenez, D. R. and Gilliam, M. (1990): Ultrastructure of the ventriculus of the honey bee, Apis mellifera (L.): Cytochemical localization of acid phosphatase, alkaline phosphatase, and nonspecific esterase, Cell. Tissue. Res., 261: 431-443.

Katarzyna, K. and Zofia, H. (1988): Histological changes in the fat body of Apis mellifera L. during larval and pupal development, Serie D, sciences biologues, Vol. 27.

Martins, G. F., Neves, C. A., Campos, L. A. and Serrão, J. E. (2006): The regenerative cells during the metamorphosis in the midgut of bees, 37(2): 161-168. 
Neves, C. A., Bhering, L. L., Serrão, J. E. and Gitirana, L. B. (2002): FMRF amidelike midgut endocrine cells during the metamorphosis in Melipona quadrifasciata anthidioides (Hymenoptera : Apidae), Micron, 33:453-460.

Neves, C. A., Gitirana, L. B. and Serrão, J. E. (2003): Ultrastructural study of the metamorphosis in the midgut of Melipona quadrifasciata athidioides (Apidae. Meliponini) worker, Sociobiology, 41: 443-459.

Raes, H., Verbeke, M., Meulemans, W. and de Coster, W. (1994): Organisation and ultrastructure of the regenenerative crypts in the midgut of the adult worker honeybee (L. Apis mellifera), Tissue and Cell, 26 (2): 231-238.

Rost, M. M., Kuczera, M., Malinowska, J., Polak, M. and Sikor, B. (2005): Midgut epithelium formation in Thermobia domestica (Packard) (Insecta, Zygentoma), Tissue and Cell., 37:135-143 Sadrud-Din, S., Loeb, M. and Hakim, R. (1996): In vitro differentiation of isolated stem cells from the midgut of Manduca sexta larvae, Journal of Experimental Biology, 199: 319-325.

Serrão, J. E. and Cruz-Landim, C. D. (1995a): The striated border of digestive cells in adult stingless bees (Hymenoptera, Apidae, Meliponinae), Cytobios, 83: 229235.

Serrão, J. E. and Cruz-Landim, C. D. (1995b): Gut structures in adult workers of necrophorous neotropical stingless bees (Hymenoptera, Apidae, Meliponinae), Entomol Gener., 19 (4): 261-265 .

Silva-Olivares, A., Diaz, E., Shibayama, M, Tsutsmi, V., Cisneros, R. and Zuniga, G. (2003): Ultrastructural study of the midgut and hindgut in eight species of the genus Dendroctonus Erichson (Coleoptera: Scolytidae), Annals of Entomological Society of America, 96: 883-900.

Snodgrass, R. E. (1984): Anatomy of the honeybee. Comstock Publishing Associates, A division of cornell university press .Ithaca and London. Fourth printing, 332 pp . 


$$
\begin{aligned}
& \text { در اسة مقارنة في التركيب النسيجي للمعي الأوسط لملكة وشغالة نحل العسل المحلي }
\end{aligned}
$$

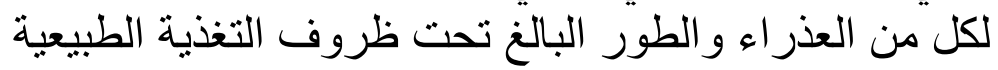

$$
\begin{aligned}
& \text { دلال مصلح الجدعاني *، أحمد عبد الله آل الغامدي **، رقية محمد المحمادي } \\
& \text { *، *** جامعة الملك عبد العزيز - جدة - المملكة العربية السعودية }
\end{aligned}
$$

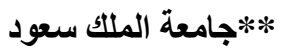

تناولت هذه الدراسـة مقارنـة التركيب النسيجي للمعي الأوسط (المعدة) لملكـة وشـالة نحل العسل اليمنـي (البلدي) حيث أظهرث النتائج الدقة والإعجاز في التركيب لهذه الحشـرة فقد وجد اختلافـات في مـا بين الملكة

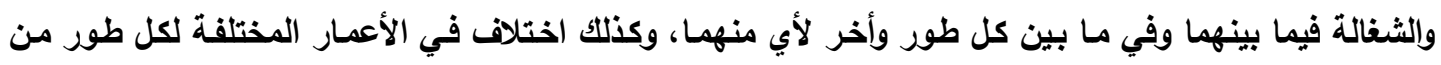

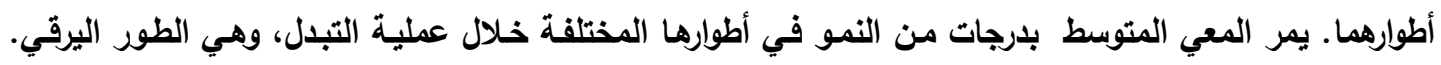

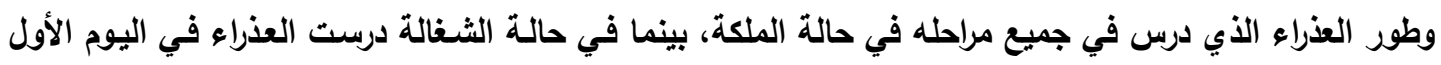

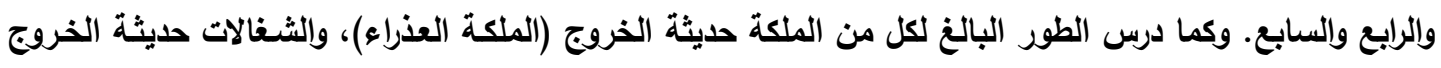

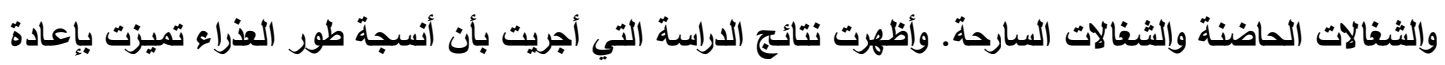

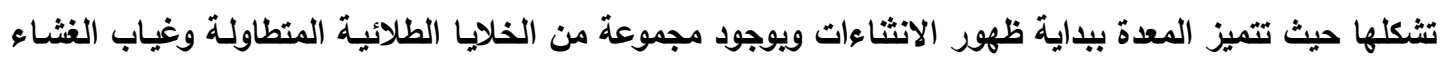

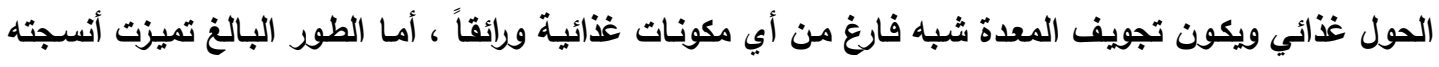

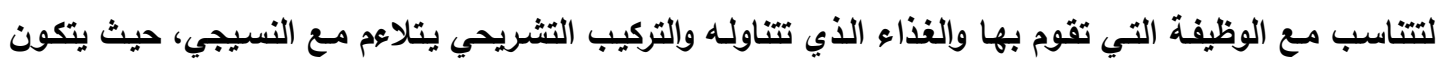

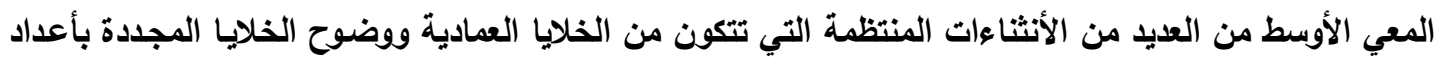

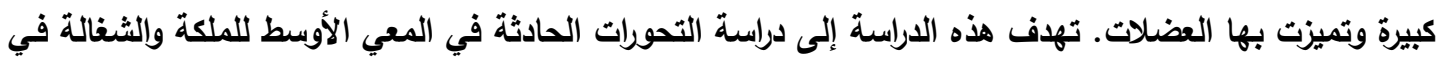

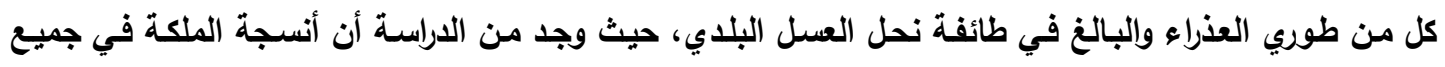

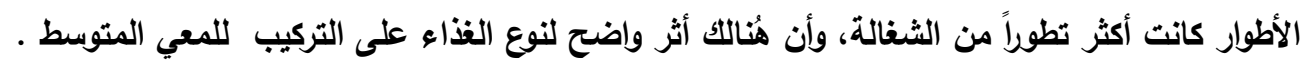

